Volume 52

Issue 2 Winter 2002: Symposium - Export/

Import: American Civil Justice in a Global

Article 13

Context

\title{
A Becoming Modesty - U.S. Litigation in the Mirror of International Law
}

Paul B. Stephan

Follow this and additional works at: https://via.library.depaul.edu/law-review

\section{Recommended Citation}

Paul B. Stephan, A Becoming Modesty - U.S. Litigation in the Mirror of International Law, 52 DePaul L. Rev. 627 (2002)

Available at: https://via.library.depaul.edu/law-review/vol52/iss2/13

This Article is brought to you for free and open access by the College of Law at Digital Commons@DePaul. It has been accepted for inclusion in DePaul Law Review by an authorized editor of Digital Commons@DePaul. For more information, please contact digitalservices@depaul.edu. 


\title{
A BECOMING MODESTY- U.S. LITIGATION IN THE MIRROR OF INTERNATIONAL LAW
}

\author{
Paul B. Stephan*
}

\section{INTRODUCTION}

United States judges may ask themselves a question that many Americans have posed since September 11: Why does the world hate us when we do so much good? Lawyers in the United States see our institutions of civil litigation as both a means for redressing many of the world's evils and a model for others to emulate. Yet, international legal organs have raised the possibility that the elements of this system violate international law. Can a judicial system that we think of as a paragon of justice fail to meet, in the eyes of international lawyers, minimum standards of fairness and decency?

Within this conflict lies the hint of new ways of thinking about a deeper problem. United States civil litigation functions in an international system, but we have not fully worked out the implications of its embeddedness. The international law critique of U.S. practice points to the difficulties of holding out our brand of justice for all comers. United States judges cannot ignore the impact of their actions on other countries and legal systems. But heeding the rest of the world

* Percy Brown. Jr. Professor of Law and E. James Kelly, Jr. - Class of 1965 Research Professor. University of Virginia. I am grateful to Curtis Bradley. Pamela Clark. Jack Goldsmith. John Jeffries, participants in the 2002 Clifford Symposium on Civil Litigation, and workshop participants at the University of Virginia School of Law and first meeting of the International Law in Domestic Groups Interest Group of the American Society of International Law for comments and criticism. They are blameless for the errors that remain. My work as an expert witness on behalf of Sukhoi Design Bureau in Pompano Air Ctr. v. Sukhoi Design Bureau. No. 96-2883-Civ. (S.D. Fla.) (settled out of court), the Bank of New York in Pavlov v. Bank of New York. 1.35 F. Supp. 2d 426 (S.D.N.Y. 2001). Philip Morris Co. in Republic of the Marshall Islands v. An. Tobacco Co., Civ. No. 1997-261 (High Ct. M.I.). Films By Jove. Inc. in Films Bv Jove, Inc. v. Berov, 154 F. Supp. 2d 432 (E.D.N.Y. 2001), Russian Aluminum in Base Metal Trading S.A. v. Russian Aluminum. No. 00 Civ. 9627. 2002 U.S. Dist. LEXIS 8516 (S.D.N.Y. May 13. 2002), and Archangelskoe Geologodobychnoe Company in Archangel Diamond Corp. v. Lakoil, 01-CV6514 (D. Colo. 2001), has informed my thinking on some of the issues involved in this paper. In none of those cases, however, did I offer opinions on either the content of United States law, or on the international law issues I consider here.

This article is dedicated to the memory of Paul B. Stephan, Jr., my father, who died three days before the Clifford Symposium began. His commitment to civility and decency in matters both public and private remains my lodestar. 
may force some of us to give up the ambition we have for our system of civil justice. Our courts might surrender some of their pride in favor of a more becoming modesty.

In particular, I want to compare normative visions about the U.S. judicial mission in foreign relations with those respecting the Executive and Congress. Commentators who wish U.S. judges to take on a broader role in addressing international injustice often deplore U.S. unilateralism by the Executive or Congress. The reverse is also true: skeptics of collective security, typically jealous of national sovereignty, express alarm at bold judicial action affecting foreign affairs. These postures are paradoxical only if one views the judicial branch as in some sense interchangeable with the others, both generally as a source of policy and values and particularly as an instrument of foreign relations. I argue for a conception of the judiciary that distinguishes its function from that of the political branches and thus detaches conceptions about the international role of judges from debates about the proper posture of the United States toward the rest of the world.

I first address two parallel and paradoxical trends involving U.S. litigation and international law. I describe how U.S. courts have sought to widen their influence over the provision of succor to foreign victims of cruelty and injustice. This development rests not only on expansive interpretations of substantive law, such as the Alien Tort Statute of 1789 and the Racketeering Influenced and Corrupt Organizations Act (RICO) of 1970, but also on shifts in doctrines such as personal jurisdiction, forum non conveniens, comity, and choice of law. I concentrate on the Second Circuit, the court that has both led the substantive movement and decided the most significant procedural cases. In general, that court has made it easier for foreign plaintiffs to bring suits involving largely foreign events, harder for defendants to have such suits dismissed before substantial evidentiary proceedings, and more likely that dismissals will turn on the court's comfort with the operation of the legal system in the country where the transaction occurred and belief in the willingness of that country's lawyers to learn from U.S. judges. I argue that a desire to increase the capacity of U.S. judges to instruct the world explains, at least in part, these developments.

I then review how international arbitral bodies have had new opportunities to scrutinize the fairness and efficacy of civil litigation in the United States and tend to find our civil process wanting. Just at a time when actors in the U.S. legal system wish to export (dare I say globalize?) the U.S. brand of justice, some voices in the international law system have suggested that this is a defective product. I look par- 
ticularly at challenges to U.S. civil litigation that Canadian firms have brought under Chapter 11 of the North American Free Trade Agreement (NAFTA). None of these proceedings has reached resolution, but they indicate a critique of civil justice in the United States that cuts to the heart of the system's aspirations to serve as a model for the world.

I proceed from these descriptive tasks to the development of alternative idealizations of judicial function. I offer two stylized accounts of what a civil litigation process might set out to do. What I will call the expressive function involves a deliberative process that engages more than the parties to the suit. The judge acts as if he or she were involved in an extended conversation both synchronically-the proceedings reshape our perceptions of the past and guide our expectations for the future-and socially-the lawsuir addresses society at large and seeks in some measure to alter or confirm the social status quo. What I will call the distributive function involves a contest among the parties before the court over the assignment of discrete interests, duties, powers, immunities, and rights. The distinction is of course artificial, as modern litigation typically fulfills both functions to varying degrees. But the distinction helps to identify which approaches to litigation more closely resemble the expressive or the distributive function.

I then explore the different implications of these functions for the judiciary's posture toward the Executive and Congress. I argue that the expressive function does not require a distinction between the judiciary and other branches of government, as the engagement in deliberative discourse has only an accidental connection to the medium of the lawsuit. The distributive function, by contrast, suggests a distinct role for the judiciary and thus invites consideration of how the operation of the political branches might restrict the scope of judicial activity.

I argue that the ambitious use of U.S. civil justice for righting international wrongs principally reflects the expressive function. ${ }^{1}$ The jus-

1. A terminological note is necessary. Some scholars distinguish between the transnational and the international, arguing that the latter term is reserved for state-to-state transactions. See. e.g., Harold H. Koh, Why Do Nations Obey International Law?, 106 YAl.E L.J. 2599. 2624-28 (1997). Although as an abstract proposition such literalism might prove clarifying, the common parlance finds "international" used generously to embrace the transnational as well. Thus, when the Second Circuit considered actions taken by a private person, the purported head of the unrecognized Serbian Bosnia, to harm other private persons. namely Bosnian civilians, or when it contemplated a private corporation's liability for the death and torture of Nigerian private persons. it spoke of violations of international. not transnational law. Kadic v. Karadzic. 70 F.3d 232, 238-39 (2d Cir. 1995): Wiwa v. Royal Dutch Petroleum Co., 226 F.3d 88, 91.92 (2d Cir. 
tification for expanding the reach and influence of U.S. courts rests mostly on arguments about the broader and nonmaterial benefits of such suits, not the needs of the parties. The international critique has more in common with the distributive function, in as much as it faults the U.S. civil litigation system for disrupting the legitimate expectations of foreigners.

In the remainder of this Article, I explore the hidden pitfalls of an expressive judiciary working in an international context. Judicial decisions create material consequences, especially in terms of incentives to bring future suits, that may diverge from the nonmaterial goals of the expressive process. Courts inevitably will have to choose on what issues to express themselves, but cannot rely on either the decisions of litigants or the logic of the expressive function itself to make these choices. Blurring the boundaries between the judiciary and other branches of government runs a risk of eroding expertise, deference, and reputation of that branch to the general detriment of civil justice. Finally, the actions of U.S. judges, rather than prompting reform elsewhere in the world, might invite hostility and retaliation directed against persons who do not take part in expressive U.S. litigation.

The obvious way in which U.S. courts have increased their capacity to entertain civil suits based on foreign events is through expansive interpretation of substantive, typically statutory, law. The most notorious instance of this strategy involves the Alien Tort Statute of 1789, a "legal Lohengrin" until its discovery by the Second Circuit in $1980 .{ }^{2}$ That court transformed a justifiably obscure procedural provision into a platform for a wide range of international human rights suits. In addition, the courts have stretched the subject matter jurisdiction of well-established regulatory regimes, such as RICO, the securities laws, and the Sherman Act, to cover foreign transactions. These developments have received much commentary and debate, none of which I wish to revisit here. ${ }^{3}$

2000), cert. denied, 532 U.S. 941 (2001), on remand. No. 96 CIV. 8386 (KMW), 2002 WL 319887 (S.D.N.Y. Feb. 28, 2002). Throughout this article, I too will use the word "international," as applied to law, relations, and context, in the colloquial if sloppy sense that comprises transnational.

2. 28 U.S.C. $\$ 1350$ (1994). Compare ITT v. Vencap Ltd., 519 F.2d 1001. 1015 (2d Cir. 1975) (describing provision as "legal Lohengrin"), with Filartiga v. Peña-Irala, 630 F.2d 876 (2d Cir. 1980) (embracing expansive interpretation of provision).

3. A partial sampling of the debate over the interpretation of the Alien Tort Statute, in addition to articles in this symposium, includes Curtis A. Bradley, The Alien Tort Statute and Article III, 42 VA. J. INT'L L. 587 (2002); Curtis A. Bradley, The Costs of International Human Rights Litigation, 2 CH. J. INT'L L. 457 (2001): William S. Dodge. The Constitutionality of the Alien Tort Statute: Some Observations on Text and Context. 42 VA. J. INI"L L. 687 (2002): William S. Dodge. Which Torts in Violation of the Law of Nations?. 24 HASTINGS INT"L \& COMP. L. REV. 351 
The less widely remarked ways of expanding the power of U.S. courts to address the problems of the world involve procedural moves that give the courts greater discretion to hear cases involving foreign transactions and to advise foreign courts on how to behave. Recent case law has moved in this direction, at least in the court of appeals that has taken the lead in developing the substantive law that vindicates foreign wrongs. The statements of the judges as well as the generally enthusiastic academic commentary indicate that these moves reflect a greater desire to influence the practice of other countries' courts and governments.

A seemingly unrelated development in international law sounds a jarring note. Over the past few decades, the United States has led a movement to embody in treaty obligations a commitment to protect foreign investors from host state expropriations. These obligations do not forbid all expropriations but do require adequate compensation and provide for independent arbitration of disputes. In recent years, foreign companies that have suffered from the U.S. civil litigation system have sought compensation on the ground that the system operates in violation of these treaty commitments. ${ }^{4}$ The implication of these claims is that civil justice in the United States, far from offering a shining beacon of light to the rest of the world, fails to meet minimal standards of fairness and decency. I briefly review these developments.

\section{A. Personal Jurisdiction}

If the U.S. courts are to address the problems of the world, they first must reconcile the traditional conception of a lawsuit as involving parties subject to the court's power with the unhappy fact that many of the people and institutions that cause these problems do not reside within the United States. In formal doctrinal terms, U.S. courts must

(2001); William S. Dodge. The Historical Origins of the Alien Tort Statute: A Response to the "Originalists," 19 Hastings INT' L \& Comp. L. Rev. 221 (1996); Harold H. Koh. Is International Law Really State Law?, 111 Harv. L. REv. 1824 (1998); Julian G. Ku, Customary International Law in State Courts. 42 VA. J. INT'L L. 265 (2001): Gerald L. Neuman. Sense and Nonsense About Customary International Law: A Response to Professors Bradley and Goldsmith, 66 FoRDHaM L. Rev. 371 (1997); Beth Stephens, Taking Pride in International Human Rights Litigation, 2 CHI. J. INT'L L. 485 (2001). For instances of expansive uses of regulatory statutes, see Kruman v. Christie's Int'l, 284 F.3d 384 (2d Cir. 2002) (claims under Sherman Act): Pavlov v. Bank of N.Y. Co. RICO Bus. Disp. Guide II 10,186 (2d Cir. 2002) (claims under RICO); Consol. Gold Fields PLC v. Minorco, S.A.. 871 F.2d 252 (2d Cir. 1989) (claims under Securities and Exchange Act and the Sherman Act).

4. For a fuller discussion of these developments, see Paul B. Stephan, Redistributive Litigation-Judicial Innovation. Private Expectations and the Shadow of International Law. $88 \mathrm{VA}$. L. REv. 789. 835-38 (2002). 
have not only jurisdiction over the subject of the dispute, but also personal jurisdiction over the parties. Where defendants in civil suits cannot be found within the territory of the court's jurisdiction, the court must justify why it nonetheless will assert power over those persons.

The cases that launched the enterprise of globalizing U.S. justice depended mostly on "tag" jurisdiction to elide the problem of judicial power. Peña-Irala, the Paraguayan policeman who allegedly tortured and murdered the relative of the plaintiffs, had come to the United States as a visitor and was served with process while under Immigration and Naturalization Service custody awaiting deportation. ${ }^{5}$ Karadzic, the embattled ruler of the ersatz Serbian Bosnia, was served with process while in New York attending a United Nations meeting. ${ }^{6}$ This strategy, while effective enough to initiate lawsuits, depends on the haphazard chance of a wrongdoer turning up in the United States, and it almost guarantees that the defendant will be judgment-proof. The odd dictator aside, most casual travelers to the United States, murderers and torturers especially, do not bring with them or leave behind significant attachable assets. ${ }^{7}$

A recent trend in international litigation responds to this problem. The defendants of choice now are large multinational firms, typically publicly traded and therefore sensitive to U.S. public relations. ${ }^{8}$ The most prominent example involves Royal Dutch Petroleum and Shell Transport and Trading, the holding companies for an oil major accused of aiding and abetting the oppression of the Ogoni people of Nigeria and the judicial murder of Ogoni leaders. These firms, respectively Dutch and British, retained an investors relations office in New York, operating under the corporate umbrella of Shell Oil, their wholly owned U.S. subsidiary, that directed publicity about their activities toward actors in the capital markets. The Second Circuit in Wiwa v. Royal Dutch Petroleum Co. ${ }^{9}$ ruled that this office served as an

5. Filartiga, 630 F.2d at 878-79.

6. Kadic. 70 F.3d at 237.

7. An exception was former Philippine President Fernando Marcos, who did have significant U.S. assets that later litigants could attach. Hilao v. Estate of Marcos, 25 F.3d 1467 (9th Cir. 1994): Republic of Philippines v. Marcos. 862 F.2d 1355 (9th Cir. 1988).

8. Curtis Bradley has described this development as a "second wave" of alien tort litigation. Curtis A. Bradley, Customary International Law and Private Rights of Action, I CHI. J. INT"L L. 421 (2000). For a more extensive discussion. see Symposium. Holding Multinational Corporations Responsible under International Law, 24 Hastings InT'L \& Comp. L. Rev. 285 (2001).

9. 226 F.3d 88 (2d Cir. 2000), cert. denied, 532 U.S. 941 (2001), on remand No. 96 CIV. 8386 (KMW), 2002 WL 319887 (S.D.N.Y. Feb. 28, 2002). Other lawsuits against corporations include those filed recently against Coca-Cola and Drummond for their alleged sponsorship of violence against labor organizers in Colombia. Gunned Down. EConomist. Mar. 23. 2002. at 36: David Bacon, The Coca-Cola Killings. Am. Prospect. Jan. 28. 2002. at 13. The Ninth Circuit has en- 
agent of the defendants and thus subjected them to the jurisdiction of New York courts for all purposes (what is known doctrinally as general jurisdiction).

The Wiwa decision, to be sure, is not the only relevant case, and U.S. courts have not always permitted aggressive theories of personal jurisdiction to hold foreign firms accountable for their wrongdoing. In Doe v. Unocal Corp.,$^{10}$ a lawsuit alleging the use of slave labor to build a pipeline in Burma, the Ninth Circuit upheld the dismissal of Total S.A., a French oil company, as a defendant. Total had a U.S. subsidiary, but the court refused to impute the subsidiary's presence to the parent. None of Total's contracts with Unocal, another defendant and unambiguously a person subject to the court's jurisdiction, involved the United States. It is noteworthy, however, that the Ninth Circuit simply affirmed on the basis of the decision of the lower court without investing in any language that might commit it to further results down the road.

A pragmatic logic supports Wiwa, although the Second Circuit's opinion does not say as much. Unless victims of international injustices can seek relief against deep-pocket defendants amenable to U.S. judicial power, they will have less of an incentive to seek redress for their injuries from the U.S. judiciary. To broaden the class of suitable defendants, U.S. courts must stretch those jurisdictional rules that govern the activity of multinational firms with complex corporate structures. The stretching does not require new doctrines so much as novel and expansive applications of old ones.

dorsed the legal theory under which a corporation can be held liable for its passive cooperation with a government engaged in slave labor, murder, and rape. Doe I v. Unocal Corp.. No. 0056603. 2002 WL 31063976 (9th Cir. Sept. 18. 2002). For cases recognizing federal court competence over claims against corporations, but rejecting each due to deficiencies in pleading. jurisdiction, or evidence. see Bano v. Union Carbide Corp., 273 F.3d 120 (2d Cir. 2001) (claim of environmental genocide); Doe v. Unocal Corp., 248 F.3d 915 (9th Cir. 2001) (per curiam) (claim of slave labor): Bigio v. Coca Cola Co., 239 F.3d 440 (2d Cir. 2000) (claim of expropriation and religious discrimination): Beanal v. Freeport-McMoran, Inc., 197 F.3d 161 (5th Cir. 1999) (claim of environmental genocide); Jota v. Texaco, Inc., 157 F.3d 153 (2d Cir. 1998) (claim of environmental genocide); Torres v. S. Peru Copper Corp., 113 F.3d 540 (5th Cir. 1997) (claim of environmental injury): Ullonoa Flores v. S. Peru Copper Corp., No. 00 CIV. 9812(CSH), 2002 WL 1587224 (S.D.N.Y. July 16. 2002). (claim of environmental injury): Abrams v. Société Nationale Des Chemins De Fer Français, 175 F. Supp. 2d 423 (E.D.N.Y. 2001) (claim of genocide); Iwanowa v. Ford Motor Co., 67 F. Supp. 2d 424 (D.N.J. 1999) (claim of slave labor); and BurgerFischer v. Degussa $A G, 65$ F. Supp. 2 d 248 (D.N.J. 1999) (claim of genocide).

10. 248 F.3d 915 (9th Cir. 2001). See also Dardana Ltd. v. A.O. Yuganskneftegaz. No. 00 CIV. 4633(DAB) 2001 U.S. Dist. LEXIS 16078 (S.D.N.Y. Sept. 21. 2001) (dismissing on personal jurisdiction grounds a suit against a foreign firm that had U.S. investment bankers and lawyers). 


\section{B. Forum Non Conveniens}

Since World War II, U.S courts have generally broadened their subject matter and personal jurisdiction. ${ }^{11}$ These trends, if left unchecked, would expose the courts to a raft of suits that, although satisfying the technical requirements of judicial competence, nonetheless would burden the judiciary and expand the opportunities of forum shoppers to exploit the system. Rather than developing a more finely tuned approach to the two types of jurisdiction, the courts instead have developed a third doctrine that allows courts to kick out suits over which they have judicial power, but for some reason seem to present especially serious risks of forum exploitation.

Forum non conveniens, the doctrine in question, rests on a handful of Supreme Court cases, the most recent of which involved a foreign transaction. ${ }^{12}$ It vests in the trial court discretion to dismiss a suit, otherwise properly before the court, where an adequate alternative forum exists to hear the case, and the balance of private interests affecting the parties and of public interests affecting the forum lies in favor of the alternative forum. Piper Aircraft Co. v. Reyno, ${ }^{13}$ the leading decision, makes clear that the doctrine functions principally as a means of combating forum shopping. It declares that the adequacy of the alternative forum does not turn on the underlying substantive law. That a change in venue would effectively destroy the value of a claim, Piper Aircraft indicates, does not bar application of the doctrine.

After Piper Aircraft, one might think that federal district courts have the discretion, although not necessarily the obligation, to dismiss suits involving essentially foreign disputes. A trio of Second Circuit cases, however, have imposed substantial barriers against the invocation of forum non conveniens in cases involving international injustice. In Jota v. Texaco, Inc. ${ }^{14}$ the court reversed the dismissal of a suit accusing a U.S. corporation of causing environmental harm in Ecuador in spite of the suit's identity with an earlier claim brought in Texas and dismissed for forum non conveniens. ${ }^{15}$ In the aforementioned Wiwa case, the court asserted that when the plaintiff resided in the United States (although not in the jurisdiction of the lawsuit) and the claim

11. For a general discussion of these developments, see George A. Rutherglen, International Shoe and the Legacy of Legal Realism, 2001 Sup. CT. Rev. 347.

12. Piper Aircraft Co. v. Reyno, 454 U.S. 235. (1981); Koster v. Lumbermens Mut. Cas. Co., 330 U.S. 518 (1947); Gulf Oil Corp. v. Gilbert, 330 U.S. 501 (1947).

13. 454 U.S. 235 (1981).

14. 157 F.3d 153 (2d Cir. 1998), reversing Aquinda v. Texaco, Inc., 945 F. Supp. 625 (S.D.N.Y. 1996). The district court, upon reconsideration, reinstituted its dismissal of the case, a disposition that was affirmed by Aquinda v. Texaco, Inc., 303 F.3d 470 ( 2 d Cir. 2002).

15. Sequihua v. Texaco, Inc., 847 F. Supp. 61 (S.D. Tex. 1994). 
rested on international law, a forum non conveniens dismissal normally would be impermissible. ${ }^{16}$ In Iragorri v. United Technologies Corp. ${ }^{17}$ the court intimated that plaintiffs could exercise a veto over forum non conveniens dismissals by asserting that the alternative forum presented risks to their personal security, even if the plaintiffs resided in that jurisdiction. ${ }^{18}$ Together, these holdings greatly diminish a trial court's discretionary authority to dismiss a foreign dispute, at least if the underlying claim sounds in international law.

The rationale of the Second Circuit's cases is frankly substantive. Certain issues, especially those involving international wrongdoing, are too important to be left to foreign courts. The U.S. courts must not shrink from their leadership role in developing a body of law that extends beyond U.S. borders. If fulfillment of this role induces greater forum shopping, and thereby increases the value of plaintiffs' claims, so much the better.

\section{Choice of Law}

It is commonplace that choice-of-law rules lead a forum court to make a determination of law that is not its own. Under the Erie doctrine, for example, we expect federal courts to surmise the content of state law, including the inchoate precedential rules that state courts have not yet announced. ${ }^{19}$ Less frequently, U.S. courts will ascertain and apply the law of a foreign nation. Traditionally, however, courts have made pronouncements about foreign law with considerable diffidence, unless the foreign rule is clearly stated and intertwined with substantial commercial practice. The decisions convey a sense of rectitude and deference, suggesting a reluctance to intrude on the lawmaking processes of a foreign sovereign.

16. Wiwa, 226 F.3d at 99-108.

17. 274 F.3d 65 (2d Cir. 2001).

18. $I d$. at 75 . To be precise, the plaintiffs resided in Bogotá. but voiced a fear about Cali. the place where the transaction at the heart of the dispute occurred, and the Second Circuit only required the trial court to consider this claim. not to give it determinative weight. For other recent cases where the Second Circuit reversed a lower court's dismissal on forum non conveniens grounds, see Bank of Commerce and Credit Int'l (Overseas) Lid. v. State Bank of Pakistan. 273 F.3d 241 (2d Cir. 2001) and Dirienzo v. Philip Servs. Corp.. 232 F.3d 49 (2d Cir. 2000). For lower court cases involving foreign transactions where courts, citing one or more of these Second Circuit cases, have rejected motions for forum non conveniens dismissal, see Conti Zweite Cristallo Schiffarhrts GmbH v. PPG Indus., Inc., No. 99 Civ. 10545(RCC), 2001 WL 1154690 (S.D.N.Y. Sept. 28, 2001); Jacobs v. Felix Bloch Erben Verlag, 160 F. Supp. 2d 722 (S.D.N.Y. 2001); Cromer Fin., Ltd. v. Berger. 158 F. Supp. 2d 347 (S.D.N.Y. 2001); Leutwyler v. Office of Her Majesty Rania al-Abdullah. 184 F. Supp. 2d 277 (S.D.N.Y. 2001): Deston Songs L.L.C. v. Wingspan Records, No. 00 CIV 8854 (NRB). 2001 WL 799811 (S.D.N.Y. July 16. 2001): Byrne v. British Broad. Corp. 132 F. Supp. 2d 229 (S.D.N.Y. 2001 ).

19. Erie R.R. v. Tompkins, 304 U.S. 64 (1938). 
A recent and notorious Second Circuit case, however, has suggested a more ambitious project for traditional choice-of-law rules. In ItarTass Russian News Agency v. Russian Kurier, Inc., ${ }^{20}$ the Russian plaintiff claimed that a U.S. newspaper violated its copyright by publishing stories in the United States that first appeared in Russian newspapers and magazines. The U.S. newspaper argued, inter alia, that the plaintiff, a news organization, lacked standing because only the authors of the stories, and not the publisher, enjoyed copyright protection. The court, in an issue of first impression, ruled that ownership of a copyright turned on the law of the place of first publication, not of the place of infringement. It then launched into a detailed inquiry as to the Russian law of copyright, ultimately deciding that the publishers did not have a protected interest. ${ }^{21}$

Several things are striking about Itar-Tass. First, the decision seems completely unnecessary. The wrongdoing (the alleged infringement) occurred in the United States, giving the United States an unmistakable interest in determining the scope and limits of protection. Standing is one part of that scope. The Berne Convention and the language of the 1988 Berne Convention Implementation Act do not require a different result; the best the Second Circuit could do is argue that these sources of positive law do not mandate the application of U.S. law to the issue. All prior cases and commentary had assumed that U.S. law applied.

Second, the decision to apply Russian law is especially problematic because of its uncertain nature. Until the introduction of elements of a market economy, that nation had only the most formal of engagements with intellectual property law generally and copyright law in particular. Even now, more than a decade after the end of the Soviet Union, most copyright rules remain precatory and aspirational. Pre-

20. 153 F.3d 82 (2d Cir. 1998).

21. For cases where lower courts have followed ltar-Tass in interpreting and applying foreign law regarding copyright. see Films By Jove, Inc. v. Berov. 154 F. Supp. 2d 432 (E.D.N.Y. 2001). and Bridgeman Art Library, Ltd. v. Corel Corp., 25 F. Supp. 2 d 421 (S.D.N.Y. 1998). As noted above, I served as an expert on questions of Russian law for the plaintiff in the Films By Jove case. The commentary on Itar-Tass, much of it critical, includes: Graeme B. Dinwoodie. International Intellectual Property Litigation: A Vehicle for Resurgent Comparativist Thought?, 49 Ам. J. Comp. L. 429 (2001): Graeme B. Dinwoodie, The Development and Incorporation of International Norms in the Formation of Copyright Law, 62 Oнıо ST. L.J. 733 (2001); Graeme B. Dinwoodie, A New Copyright Order: Why National Courts Should Create Global Norms, 149 U. PA. L. Rev. 469 (2000): Graeme W. Austin. Social Policy Choices and Choice of Law for Copyright in Cyberspace, 79 OR. L. Rev. 575 (2000); David E. Miller, Finding a Conflicts Issue in International Copyright Litigation: Did the Second Circuit Misinterpret the Berne Convention in Itar-Tass? 8 Cardozo J. INr'L \& Comp. L. 239 (2000); Jane C. Ginsburg. The Cyberian Captivity of Copyright: Territoriality and Authors' Rights in a Networked World, 15 COMPUTER \& HiGH TECH. L.J. 347 (1999) 
cise questions of ownership turn on the legitimacy of convoluted enterprise reorganizations and privatization transactions that took place during a period of radical legal instability. Neither the indigenous academic nor judicial commentary is developed enough to resolve most problems. Perhaps the Second Circuit believed that its conjectures about the content of Russian law would help by giving guidance to those fighting for the rule of law in that country in the guise of "interpretation." But if such an impulse motivated the court, it ignored the risks of its intervention.

The core problem with the Second Circuit's new approach to choice of law in copyright is that it induces foreign jurisdictions with underdeveloped legal systems to decide questions that will have significant economic consequences in the more prosperous parts of the world, the United States first among them. This creates an incentive for foreign courts to decide these questions in a way that promotes short-term benefits to locally influential people, rather than in ways that contribute to the rule of law. I have suggested elsewhere that, where a foreign court interprets its copyright law in a startling new fashion that has the earmarks of an expropriation, a U.S. court would have a basis for refusing to respect the foreign determination. ${ }^{22}$ But the possibility of such a difficult and painful confrontation would never arise if the Second Circuit instead had regarded standing as an integral part of the U.S. right subject to infringement.

\section{Comity}

The doctrine of comity regarding foreign judicial proceedings is one of the more amorphous legal constructs to complicate litigation with international aspects. It can trace its origin to a nineteenth century case dealing with the enforceability of a foreign court judgment. ${ }^{23}$ In recent times, however, it has become a means for U.S. courts to extend or withhold their solidarity with foreign actors in a wide variety of contexts, not only judicial. ${ }^{24}$ It has particular force in the case of

22. Cf. Stephan, supra note 4. at 805-07.

23. See Hilton v. Guyot, 159 U.S. 113 (1895). This foundational case, which arose during a time when Swift v. Tyson. 41 U.S. (16 Pet.) 1 (1842). still held sway. applied general common law rather than any particular treaty or federal or state common law. Its authority today thus rests on prestige rather than any fixed precedential force. See Curtis A. Bradley \& Jack L. Goldsmith, Customary International Law as Federal Common Law: A Critique of the Modern Position. 110 Harv. L. Rev. 815. 822-26 (1997); Jack L. Goldsmith. Federal Courts, Foreign Affairs, and Federalism. 83 VA. L. REv. 1617. 1639-40 (1997).

24. E.g. Allied Bank Int'l v. Banco Credito Agricola de Cartago. 733 F.2d 33 (2d Cir. 1984) (finding foreign government order not to honor bank loans sufficient for dismissal of U.S. lawsuits to enforce contract because nonenforcement was consistent with the law and policy of the United States). reversed by 757 F.2d 516 (2d Cir. 1985) (reconsidering law and policy of the 
parallel litigation in different jurisdictions. In a strategy that is broadly similar to that of forum non conveniens, the doctrine gives a court the authority, but not the duty, to dismiss U.S. litigation in favor of a foreign forum. The criteria for deferring to a foreign proceeding are a combination of procedural adequacy and concordance of foreign law with U.S. law and policy. ${ }^{25}$

In the hands of the Second Circuit, the comity doctrine has become not only a means of managing the court's caseload, but also a tool for approving the judicial process in some nations and criticizing the process of others. The requirement that foreign law reflect both the rules and policies of U.S. law serves at least two functions. It enables the court to hand out praise to foreign legal systems when deemed appropriate. ${ }^{26}$ Such actions reinforce the impression that the court regards its expressions as significant, aside from any instrumental consequences. Second, the requirement has an instrumental effect, inas-

United States after intervention by executive branch). See also Pravin Banker Assocs. v. Banco Popular Del Peru, 109 F.3d 850 (2d Cir. 1997) (giving deference to moratorium on Peruvian debt no longer required by international comity when interests of the United States have changed). Joel Paul has written a cogent critique of invocations of the comity doctrine that legitimizes judicial deference to executive branch claims that do not rest on congressional enactments. Joel R. Paul, Comity in International Law, 32 HARv. INT'L L.J. 1 (1991). See also Michael D. Ramsey, Escaping "International Comity," 83 Iowa L. Rev. 893 (1998).

25. E.g., Commodore Int'l Ltd. v. Gould, 262 F.3d 96 (2d Cir. 2001); In re Treco, 240 F.3d 148 (2d Cir. 2001); Diorinou v. Mezitis, 237 F.3d 133 (2d Cir. 2001); Bigio, 239 F.3d 440; Finanz AG Zurich v. Banco Economico S.A., 192 F.3d 240 (2d Cir. 1999); In re Maxwell Communication Corp., 93 F.3d 1036 (2d Cir. 1996); Allstate Life Ins. Co. v. Linter Group Ltd., 994 F.2d 996 (2d Cir. 1993). Comity is an especially strong form of the multilateral, as opposed to unilateral, approach to conflicts of law. For an explanation of the distinction, see William S. Dodge, Extraterritoriality and Conflict-of-Laws Theory: An Argument for Judicial Unilateralism, $39 \mathrm{HARV}$ INT'L L.J. 101 (1998). For a defense of comity that emphasizes its expressive function, see AnneMarie Slaughter, Judicial Globalization, 40 VA. J. INT'L L. 1103, 1112-15 (2000).

26. For example:

In addition to the relative strength of the respective jurisdictional interests of England and the United States, there is a compelling systemic interest . . . These parallel proceedings in the English and American courts have resulted in a high level of international cooperation and a significant degree of harmonization of the laws of the two countries ... . Taken together, these accomplishments-which, we think, are attributable in large measure to the cooperation between the two courts overseeing the dual proceedings-are well worth preserving and advancing. This collaborative effort exemplifies the "spirit of cooperation" with tribunals, guided by comity, should approach cases touching the laws and interests of more than one country .... Where a dispute involving conflicting avoidance laws arises in the context of parallel bankruptcy proceedings that have already achieved substantial reconciliation between the two sets of laws, comity argues decidedly against the risk of derailing that cooperation by the selfish application of our law to circumstances touching more directly upon the interests of another forum.

In re Maxwell Communication Corp., 93 F.3d at 1053. 
much as a country whose legal system fails to pass muster must deal with U.S. litigation that interferes with its objectives. ${ }^{27}$

\section{E. International Review}

The four developments discussed above suggest a link between direct efforts to expand the capacity of U.S. courts to address the world's problems through substantive law and indirect strategies to increase the courts' international influence. None rests explicitly on conceptions of international law, but all are informed by the courts' sense of how their statements and actions affect international relations. What they have not considered, however, is how the U.S. civil litigation system generally fits within the body of international law.

International lawyers have complained about U.S. civil litigation for almost sixty years. These critiques traditionally rest on claims about the flouting of inchoate norms rather than violation of binding commitments embodied in a formal instrument with its own enforcement structure. The traditional charge was that the United States allowed its courts to impose U.S. law on transactions that took place outside its territory and in which the United States had an insufficient interest to justify its regulation. ${ }^{28}$ More recently, some have argued that U.S. legislation or court practice does not respect the principles of sovereign immunity, both with respect to states as such and regarding the persons who serve as head of state. ${ }^{29}$ The fundamental difficulty with

27. E.g., Drexel Burnham Lambert Group, Inc. v. A.W. Galadari, 777 F.2d 877 (2d Cir. 1985) (finding United Arab Emirates bankruptcy proceeding does not merit comity).

28. E.g., Rio Tinto Zinc Corp. v. Westinghouse Elec. Corp., 1 A.C. 547 (H.L. 1978); Midland Bank PLC v. Laker Airways, Ltd., 1 Q.B. 689 (C.A. 1986). The Restatement articulates a somewhat less constraining principle, namely that litigation cannot unreasonably regulate extraterritorial transactions. Restatement (ThiRd) of The Foreign Relations Law of the United STATES $\$ 403$ (1987). The assumed existence of this customary norm creates conceptual problems for those advocating U.S. litigation attacking extraterritorial torts committed in violation of "the law of nations," pursuant to 28 U.S.C. $\$ 1350$. because it suggests that in some circumstances vindication of customary norms of human rights might violate other kinds of international law. See Beth Stephens, Translating Filártiga: A Comparative and International Law Analysis of Domestic Remedies for International Human Rights Violations, 27 YALE J. INT'L. L. 1, 53-57 (2002); Michael D. Ramsey, Multinational Corporate Liability under the Alien Tort Claims Act: Some Structural Concerns. 24 Hastings Int'L \& Comp. L. Rev. 361, 370-75 (2001). The proposed solution has been to assert yet another customary international law principle, namely the concept of universal jurisdiction. This codicil to the general principle forbidding unreasonable extraterritoriality permits a nation to disregard that principle with respect to certain violations of international law. Stephens, supra, at 49-53. One might question whether the employment of this codicil reflects much more than the need to shape international law's jurisdictional norms to meet advocates' substantive preferences.

29. The issue is whether the 1996 amendments to the Foreign Sovereign Immunities Act. abrogated immunity in connection with certain terrorism claims. and the approach of U.S. courts to head-of-state immunity transgress international norms. For a discussion, see Curtis A. Bradley 
all these arguments is that no international instrument to which the United States is a party addresses these issues, and no decisionmaker has the capacity to provide authoritative and final resolution of the international law claims. ${ }^{30}$ Disputes over the content of unwritten norms not supported by a central decisionmaker tend not to reach closure. ${ }^{31}$

But where international law rests on explicit commitment, including acceptance of an enforcement process that operates independently of the state subject to the law, we need to take notice. The most recent legal developments thus are significant precisely because of the institutional nature of the norm at issue. The cases concern Chapter 11 of NAFTA, an elaborate and detailed body of specific rules governing the expropriation of foreign investment. Chapter 11 carries with it a commitment to respect an enforcement mechanism that private persons can invoke without the mediation of their government. An investor seeking compensation for a violation of Chapter 11 may bring the offending state before an ad hoc arbitration tribunal, which has the power to impose a binding settlement of the dispute, including an award of money damages. ${ }^{32}$

Claims that have arisen under Chapter 11 of NAFTA raise the possibility that U.S. civil litigation, far from offering an inspirational model, may run afoul of international justice. Chapter 11 embodies a set of principles that the United States has championed for over a century, centered on the idea that nations that invite foreign investment may not defeat the legitimate expectations of those investors. States that do expropriate foreign investments must pay full compensation. This duty not to expropriate is distinct from an obligation not to discriminate against foreign investors; a state cannot excuse its conduct by demonstrating that it uses its own subjects just as badly. Historically, the United States has put these obligations into investment

\& Jack L. Goldsmith, Foreign Relations Law of the United States 630-31 (2003). On the relevant international law, see Case Concerning the Arrest Warrant of 11 April 2000 (Democratic Republic of the Congo v. Belgium), available at www.icj_cij.org/icjwww/idocket/iCOBE/ icdocjudgment/icdoc_judgment_20020214.PDF (last visited Nov. 8, 2002).

30. National courts do invoke these norms. E.g., Rio Tinto Zinc Corp., I A.C. 547; Midland Bank PLC, 1 Q.B. 689. Their decisions do not bind other tribunals, however, and thus are not authoritative or final with regard to the international system. E.g. Hartford Fire Ins. Co. v. California, 509 U.S. 764 (1993) (following legislative intent, not international norms, in determining extent of extraterritorial jurisdiction of U.S. antitrust law).

31. On the significance of international law embedded in international institutions with dispute resolution authority, see Paul B. Stephan. The New International Law-Legitimacy, Accountability, Authority, and Freedom in the New Global Order, 70 U. Colo. L. Rev. 1555 (1999).

32. See North American Free Trade Agreement, Jan. 1, 1994, arts. 1115-38. Annex 1120.1. 1138.2. 32 I.L.M. 296. 
treaties, which call for dispute resolution through either the International Court of Justice or a designated arbitral body. Chapter 11 is unusual only because it exists within a trade agreement that the United States adopted through legislation rather than by treaty; it otherwise fits the pattern of U.S. support for a developing law on expropriations..$^{33}$

What has surprised the United States is the willingness of arbitral tribunals to apply Chapter 11 in contexts that do not conform to the traditional naked expropriation. The tribunals have shown an openness to arguments that any government action that upsets legitimate expectations triggers an obligation to compensate. In particular, they have invited arguments that the conduct of civil litigation may violate international law.

Two cases raise this issue. The first involved a lawsuit brought by Mondev International, a Canadian firm acting on behalf of a Massachusetts limited partnership it controlled, against the City of Boston and its agency, the Boston Redevelopment Authority, for breach of contract and intentional interference with contractual relations. The Canadian company won a jury verdict of $\$ 16$ million, which the trial judge reduced to $\$ 9.6$ million and which the Massachusetts Supreme Judicial Court threw out altogether on the ground that the city could not waive its sovereign immunity. The investor then brought a claim against the United States under Chapter 11, asserting that the trial and appellate judges contrived retroactive changes in state law to destroy the value of its investment. Pursuant to the terms of Chapter 11, a three-person arbitration tribunal operating under the auspices of the International Center for the Settlement of Investment Disputes (ICSID), an agency of the World Bank, took up the matter. ${ }^{34}$

The second case arises out of a lawsuit for breach of contract and fraud brought by O'Keefe, a Mississippi funeral home, against Loewen, a Canadian company that backed out of a purchase agreement. O'Keefe, the jilted target, sued the Canadian company and its

33. For more on Chapter 11 and the general U.S. approach to investor protection, see Charles N. Brower \& Lee A. Steven. Who Then Should Judge? Developing the International Rules of Law Under NAFTA Chapter II. 2 CHI. J. INT'L. L. 193 (2001): Stephan. supra note 4, at 835-38. On the evolution of the U.S. approach to the law of expropriation. see Paul B. Stephan. Creative Destruction-Idiosyncratic Claims of International Law and the Helms-Burton Legislation, 27 Stetson L. Rev. 1341 (1998).

34. For the investor's claim, see Mondev Int'l. Ltd. v. United States, Notice of Arbitration, Sept. 1. 1999. at http://www.naftaclaims.com (last visited Sept. 20. 2002). The panel eventually determined that because the alleged misconduct of the Boston agencies arose before NAFTA had gone into effect. the judicial proceedings occurring after NAFTA's effective date presented no independent issue under Chapter 11. Mondev Int "1. Ltd. v. United States. Award. Oct. 11. 2002. at http://www.naftaclaims.com (last visited Nov. 8. 2002). 
local subsidiary in a Mississippi state court and received a judgment for $\$ 500$ million, which the trial judge upheld. The company could not afford to post the bond Mississippi law required as a condition for appeal, and therefore settled the case for roughly a third of the verdict. The company quickly descended into bankruptcy, which it attributed to the reputational injury and cash drain caused by the lawsuit. It then filed a claim under NAFTA Chapter 11, charging that the Mississippi court proceedings amounted to an expropriation. Again, a three-person tribunal operating under the ICSID auspices convened to hear the dispute. ${ }^{35}$ The tribunal has not yet ruled on the merits, but it has determined that as a matter of international law a judicial proceeding could amount to an expropriation for which Chapter 11 would require compensation. ${ }^{36}$

Of the two disputes, Loewen has attracted greater attention, because it involves a larger sum and its facts edge closer to a conventional expropriation, in which a local government ambushes a foreign investor with unexpected demands. Upon closer examination, however, both offer a disturbing portrait of the treatment of outsiders in U.S. civil litigation. ${ }^{37}$ In the Mondev case, a foreign firm, seeking to capture the benefits of an advantageous, but not corrupt, contract with a local government found itself without legal recourse after the state's highest court came up with a novel theory of sovereign immunity. In the Loewen case, a modest business dispute mushroomed into an extraordinary, indeed unbelievable, damages award. Mondev involved judicial creativity in the face of jury sympathy with an outsider, while Loewen suggests judicial passivity in the face of jury prejudice inflamed by an extravagant and outlandish plaintiff's attorney. Each offers evidence that people reasonably might fear, and not admire or welcome, the U.S. approach to civil litigation.

The Mondev and Loewen cases have contributed to a larger controversy over the appropriateness and scope of national obligations under NAFTA Chapter 11. Other tribunals have awarded compensation for regulatory actions by the Canadian and Mexican governments that imposed costs on investors but did not directly expropriate their

35. The Loewen Group, Inc. v. United States. Notice of Arbitration/Statement of Claim. Oct. 30. 1998, at http://www.naftaclaims.com (last visited Sept. 20, 2002).

36. The Lowern Group, Inc. v. United States. ICSID Case No. ARB(AF)/98/3, Award on Jurisdiction, Jan. 5, 2001, at http:/www.naftaclaims.com (last visited Sept. 20, 2002).

37. As I have observed elsewhere, the status of "outsider" in the context of expropriative litigation turns more on demographic and economic factors than on citizenship. A large portion of the surprising court awards that U.S. civil litigation produces occur in a handful of exceptionally poor counties, where any substantial enterprise seems alien. See Stephan, supra note 4. at 863-65. 
property. ${ }^{38}$ Investors have brought similar claims against the United States, although none has produced a decision on the merits. National responses fall into two categories-debate over the scope of both present and future international commitments and threats not to honor the awards. ${ }^{39}$

In the case of the United States, discussion of limiting or repudiating the Chapter 11 obligations remains hypothetical. The government of the United States did join with those of the other NAFTA parties in agreeing to a "clarification" of the scope of Chapter 11, but the language of this instrument seems quite modest. ${ }^{40}$ Some commentators have suggested that, if the occasion arises, the United States should refuse to honor arbitral awards that intrude on traditional domestic prerogatives, but no one knows what we will do. ${ }^{41}$ The general point remains clear, however: One possible response to the international law-based critiques of U.S. civil litigation emanating from the Mondev and Loewen cases is to diminish what international law can demand.

\section{Two Models of Litigation}

The tension between the ambition of U.S. judges for our civil litigation process and the fear and loathing suggested by the Chapter 11 cases reflects two different conceptions of what litigation should do. The first, what I will call the expressive function, asserts that the primary function of litigation is to serve as a nexus of discourse that will instruct and elevate both the participants and the broader public. The second, what I will call the distributive function, asserts that litigation addresses the needs of the parties before the court and has meaning and value only to the extent that the process affects their interests.

38. For description of these cases. see Charles H. Brower II. Investor-State Disputes Under NAFTA: The Empire Strikes Back, 40 Colum. J. Transnat iz L. 43, 51-61 (2001).

39. Id. at 61-68.

40. The NAFTA Free Trade Commission. consisting of representatives of the three governments. pronounced. inter alia:

1. Article $1105(1)$ prescribes the customary international law minimum standard of treatment of aliens as the minimum standard of treatment to be afforded to investments of investors of another Party.

2. The concepts of "fair and equitable treatment" and "full protection and security" do not require treatment in addition to or beyond that is required by the customary international law minimum standard of treatment of aliens.

3. A determination that there has been a breach of another provision of the NAFTA. or of a separate international agreement, does not establish that there has been a breach of Article 1105(1).

NAFTA Free Trade Commission. Notes on Interpretation of Certain Chapter I/ Provisions, July 31, 2001. at http://www.dfait-maeci.gc.ca/tna-nac/NAFTA-Interpr-e.asp (last visited Oct. 7. 2002).

41. Brower, supra note 38 , at $46-47$. 
As I describe them, both conceptions are idealizations, aspirational rather than predictive. They are models in the platonic sense, not in the scientific one. At the same time, neither is fanciful. They incorporate justifications offered by judges to explain their function and the normative claims of critical commentators. For our purposes, they expose the implications and defenses of particular strategies within the civil litigation process, in particular those that seek, on the one hand, to make U.S. courts greater within the international system and, on the other hand, to rein in U.S. litigation affecting international interests. ${ }^{42}$

\section{A. Expressive Litigation}

A lawsuit provides the state, acting through the judge as its representative, with an opportunity to make authoritative and dignified pronouncements. A leading treatise emphasizes the benefits of these statements to the parties:

A court's favorable judgment is a solemn pronouncement that the victor has acted properly on the basis of a factually accurate understanding of reality. A favorable judgment is an affirmation of the prevailing party's rationality and good citizenship .... All these benefits have a considerable psychological as well as material value. ${ }^{43}$

Litigation's audience, however, goes well beyond those who appear before the court. In articulating a sense of justice, both in the specific context of the lawsuit and in a broad normative sense of what the lawsuit teaches, litigation speaks to society as a whole. It both responds to and shapes broad intuitions of what is normatively just. It reaches into the past to build a sense of appropriateness and, at the same time, shapes our understanding of the past to strengthen our belief in the inevitability of its outcomes.

As a matter of legal theory, there exist many ways to capture the expressive function of litigation. Those of us who work in law and economics might say that litigation generates public goods in the form of more and better information about the scope and meaning of legal rules. ${ }^{44}$ Those interested in theories of justice might say that litigation

42. For my earlier use of contrasting models of judicial behavior to illuminate legal issues bearing on international relations, see Paul B. Stephan, International Law in the Supreme Court. 1990 Sup. CT. Rev. 133; Paul B. Stephan, Constitutional Limits on the Struggle Against International Terrorism: Revisiting the Rights of Overseas Aliens, 19 CONN. L. REv. 831 (1987).

43. James Fleming, Jr. Et al., Civil Procedure 307 (4th ed. 1992).

44. Cf. Ehud Kamar, Shareholder Litigation under Indeterminate Corporate Law, 66 U. CHI L. REV. 887 (1999) (arguing that insurance subsidizes corporate litigation, generating a public benefit in terms of greater development of law). 
engages society in reasoned deliberation that allows society to better articulate its sense of moral value. ${ }^{45}$ Those with a post-modern inclination might argue that litigation serves as a kind of performance through which social meaning is constructed. ${ }^{46}$ A common thread underlies each of these otherwise disparate conceptions: litigation has purposes and functions that are independent of the parties before the court. Judges and lawyers engaged in litigation represent society, whether self-consciously or not, and society in turn shapes and places its demands on those actors.

Seeing the significance of litigation as unconnected to the interests of the litigants has at least two implications. First, attenuating the link between the parties and the broader meaning of the litigation diminishes the importance of a focused historical inquiry into the facts of the case. The court should plumb the events giving rise to the dispute for their social meaning, but should also consider all other sources of significance. The trial should serve as a narrative, not as a reconstruction of something that happened. The lawyers and the judge should cast their nets as widely as possible to determine the needs of justice. Litigation engages all senses of the past, not just those of the parties, and influences how society as a whole views its history.

Second, to the extent litigation addresses audiences other than the parties, the needs and desires of the parties take on lesser importance. The litigants have provided the occasion for the expressive act, but they do not, for that reason, require special consideration. Expressive litigation thus becomes a means of, if not ignoring, at least discounting the interests of the litigants. In their place, we find the sensibilities and moral intuitions of the judge and lawyers. The expressive function, in short, is largely about replacing interested individuals with informed and, one hopes, enlightened legal professionals.

That the claims of U.S. courts in international cases rest on the expressive function seems beyond debate. Abram Chayes, one of the principal architects of ambitious international litigation, is also the author of one of the earliest and most influential expositions of the ex-

45. Cf. Owen M. Fiss. Against Settlement, 93 YALE L.J. 1073 (1984) (arguing that settlement detracts from the central function of litigation in articulating and developing a social sense of justice): Charles Nesson. The Evidence or the Event? On Judicial Proof and the Acceptability of Verdicts, 98 HARV. L. REv. 1357 (1985) (explaining rules of evidence as augmenting the instructive value of litigation as a way to engage society's sense of justice).

46. Cf. Kenneth W. Graham. Jr.. "There'll Always Be an England": The Instrumental Ideology of Evidence. $85 \mathrm{M}$ CH. L. REv. 1204 (1987) (justifying rules of evidence based on the performative function of litigation). 
pressive function. ${ }^{47}$ The seminal case on U.S. human rights litigation, the parent of the ambition that now seems central to the identity of, at a minimum, the Second Circuit, is redolent with pedagogic rhetoric. ${ }^{48}$ The Wiwa case, which restricted the discretion of trial courts to invoke forum non conveniens in cases involving international wrongdoing, explicitly invoked the court's expressive role in developing international law. ${ }^{49}$ Responding and contributing to a broad sense of international justice, and not simply addressing the needs of those persons before the court, explain the ambitious tendencies of recent litigation.

\section{B. Distributive Litigation}

An older way of looking at litigation concentrates exclusively on the interests of the parties. A leading treatise speaks of this as the coercive function: litigation involves those to whom a court may apply its coercive power and has significance to the extent that power is or is not exercised. ${ }^{50}$ The distributive function regards litigation as a service to disputants, something that also benefits society only to the extent that its members are potential litigants.

One might object that in a common law system, where the decisions of courts shape the law, the distributive conception fails to capture a large part of what litigation does. But this argument suffers from an exaggerated sense of the role of appellate decisions in the civil litigation process. The overwhelming majority of cases end up settled and therefore generate no precedent. Moreover, in an ever-widening sphere of activities, parties have the option of committing their disputes to arbitration, a process that by design fully conforms to the distributive conception. One fairly can say that in the United States, a jurisdiction where the lawmaking powers of courts seem most widely accepted and embedded in the civil litigation system, almost all disputes end up generating no law of general applicability.

47. Abram Chayes. The Role of the Judge in Public Law Litigation. 89 HARV. L. REV. 1281 (1976). For a recognition of the direct links between Chayes's vision of expression litigation and his conception of international law, see Koh, supra note 1, at 2638. For a cogent argument against extension of the public litigation model into the international arena, see Ann Woolhandler, Treaties, Self-Execution, and the Public Law Litigation Model, 42 VA. J. INT'L L. 757 (2002).

48. See, e.g., Filartiga v. Peña-Irala, 630 F.2d 876, 890 (2d Cir. 1980) (stating "[o]ur holding today. giving effect to a jurisdictional provision enacted by our First Congress, is a small but important step in the fulfillment of the ageless dream to free all people from brutal violence").

49. The Wiwa court held: "If in cases of torture in violation of international law our courts exercise their jurisdiction conferred by the 1789 Act only for as long as it takes to dismiss the case for forum non conveniens, we will have done little to enforce the standards of the law of nations." Wiwa, 226 F.3d at 106.

50. Fleming E'T AL.. supra note 43, at 295-98. 
The distributive function largely entails a retrospective inquiry into events affecting the parties to the case. It does not exclude the casting of a broader net, but it regards information about broader social conditions and attitudes as relevant only to the extent that they shed light on the parties' interests. It regards the reasons offered for the outcome not as a way of influencing others but as a means of increasing the court's accountability for its actions. It sees litigation as having mainly an ex post perspective: choosing whether and how to exercise coercion turns principally on what we believe happened, not on what meaning we believe that people will attribute to the court's choices. ${ }^{51}$

The international law norm embodied in NAFTA Chapter 11 clearly reflects a view of litigation's distributive function. Although the rules to some extent focus on purpose by forbidding all discriminatory actions, mostly they concentrate on effect. An expropriation, whether outright through seizure of property or functional through regulation that destroys property value, triggers an obligation to compensate. This principle requires a determination of what constitutes property and a causal connection between government action and destruction of value, but not any deeper search for meaning. And the application of this principle to litigation reflects an especially strong version of the distributive function. It asks only whether the litigation outcome resulted in the destruction of preexisting rights worthy of legal protection, not why the destruction occurred or what purpose it served.

As compared to the expressive function, the distributive function offers a narrower, more constrained role for lawyers and judges. These actors work in the interests of justice, but justice as circumscribed by the needs and desires of the parties before the court. Specialized professional functions become more important, and a general ability to tap into and articulate broad notions of decency and value diminishes in significance.

\section{Implications for International Relations Theory and Practice}

A substantial literature, drawing on international relations theory, rests on a conviction about the significance and value of the expressive

51. I intend particularly to distinguish the distributive function from what I elsewhere have called redistributive litigation. In my earlier work. I have argued that litigation is redistributive to the extent it alters or destabilizes reasonable expectations about rights, duties, privileges, and obligations. I have also argued that it is the prospective effect of a new rule or norm announced or implied by litigation. rather than its distribution of the parties interests, that constitutes redistribution. Stephan. supra note 4. at 796-97. The distributive function. as I use the term. concentrates on the party's interests in the dispute before the court. and not on the instrumental or expressive implications of the litigation`s outcome. 
function of litigation. This literature begins with a conception of international law as primarily engaged in "a process of justificatory discourse." 52 The development of international norms, this literature asserts, depends on judicial participation in both the epistemic community that articulates and interprets norms and the process of national internalization of those norms. ${ }^{53}$ The epistemic function closely follows the expressive: judges both join in the élite, interconnected, and self-constituting group that provides meaning to these rules and give the other participants, particularly lawyers engaged either as representatives or as amici, a privileged role in the discourse. And internalization gains force to the extent litigation not only applies the law but announces and justifies its application to the broader society.

What I find interesting about this literature is its recognition that expressive litigation is fungible with other official processes of interpreting and internalizing international norms. Harold Koh, for example, cites his litigation over the status of Haitian refugees as an instance where courts refused to embrace a norm he had advocated (a right to a full and individualized inquiry into threat of persecution whether the refugee reaches U.S. territory or not), but where the Clinton administration achieved his desired end through a process of "political internalization." 54 The underlying point here is that the expressive function is not distinct to litigation. Actions by the political branches-legislative enactment or changes in executive policy-can do as much as litigation to both interpret and internalize international norms. The question over which branch makes these changes constitutes an opportunistic choice, not a principled one.

The church of international relations theory, however, has many denominations, not all of which privilege the expressive talents of élites. An alternative stream looks at rational actors, whether states or (increasingly) interest groups and nongovernmental organizations. This strand of scholarship pays less attention to explanations offered by

52. Koh, supra note 1, at 2602 (citing Abram Chayes \& Antonia Handler Chayes. The New Sovereignty: Complance with International Regulatory Agreements 26 (1995); Thomas M Franck, Fairness in International Law and Institutions 14 (1995)).

53. See. e.g., Koh, supra note 1, at 2648, 2656-57: Harold H. Koh, Transnational Public Law Litigation, 100 YALE L.J. 2347, 2371-75 (1991): Slaughter. supra note 25, at 1109-15. On epistemic communities and networks. see Margaret E. Keck \& Kathryn Sikkink, Activists Be yond Borders: Advocacy Networks in International Politics (1998): Peter M. Haas, Introduction, Epistemic Communities and International Policy Coordination. 46 IN'T'L ORG. 1 (1992): Kathryn Sikkink. Human Rights, Principled Issue-Networks, and Sovereignty in Latin America, 47 INT'L ORG. 411 (1993). For a broader, more theoretical discussion of how discourse conducted at the international level shapes domestic norms and perceptions. see ALEXANDER Wenit, Social Theory of International Politics (1999).

54. Koh. supra note 1. at 2657. 
actors and more to actions. It argues that actors pursue strategies reflecting their interests, and that rules and structures prevailing over time better reflect those interests than those that do not. ${ }^{55}$

A rational choice, instrumentalist approach to both international relations and litigation slights the expressive function and focuses on the distributive effects of outcomes resulting from litigation. It asks not what are the participants telling us, but what are they getting? It looks to observable events and revealed preferences rather than to expressions that interpret events and preferences.

The rationalist approach has both weaknesses and strengths when applied to litigation. By excluding rhetoric, styles of justification and forensic posturing, it leaves out exactly those qualities with which lawyers tend to have particular affinity. By emphasizing modeling and empirical inquiry, it employs methodologies with which many legal academics, especially international lawyers, feel uncomfortable. But it also generates testable hypotheses. And by stripping litigation of its symbolic trappings, this approach does force the observer to focus on the distributive consequences of the process.

Of the legal developments discussed in the first section, rationalists have an easier time explaining the application of the international norm against expropriation to civil litigation than elucidating the forces behind ambitious litigation to right international wrongs. The norm against expropriation works as a solution to a collective action problem. Without some kind of protection of outsider investors, local authorities would find it rational to expropriate; the resulting equilibrium would result in suboptimal levels of investment. ${ }^{56}$ Extending this norm to litigation requires only that one not make an exception, but instead treat judicial coercion as equivalent to other exercises of state power. ${ }^{57}$

But what problem does ambitious righting of wrongs address? Because most acts of cruelty and injustice do not involve reciprocity, collective action arguments do not apply. The easiest way of

55. For a recent article by law professors that uses this branch of international relations theory to explain certain regularities in international behavior, see Jack L. Goldsmith \& Eric A. Posner. A Theory of Customary International Law. 66 U. CH. L. Rev. 1113 (1999). For a fuller discussion of instrumental rationalism in international relations theory. see ROBERT AXELROD. THE Evolution of Cooperation (1981): Robert O. Keohane. After Hegemony: CooperaTion \& Discord in the Worlod POlitical Economy (1984): International Regimes (Stephen D. Krasner ed.. 1983): Symposium, Rational Choice and International Law. 31 J. LEGAL. Srup. 1 (2002); Robert Putnam. Diplomacy and Domestic Politics: The Logic of Two-Level Games, 42 INT'L Org. 427 (1988): Duncan Snidal, Coordination Versus Prisoner's Dilemma: Implications for International Cooperation and Regimes, 79 AM. POL. SCI. REv. 923 (1985).

56. For a fuller discussion. see Stephan. supra note 4. at $841-51$.

57. Id. at $852-55$. 
understanding this point is to consider whether a jurisdiction, witnessing injustices elsewhere, might respond by committing some injustices of its own. Putting aside the case where actors have at their mercy people who have close connections to other actors (in other words, hostage situations), retaliation of this sort does not seem plausible. ${ }^{58}$

One might suggest that the litigation will deter wrongdoing and that the strong U.S. civil litigation system can serve as a coordination point for a strategy that all countries would do well to adopt. ${ }^{59}$ But much of the litigation we have witnessed has not focused on persons easily subject to the coercive powers of U.S. courts, and without effective coercion the prospects for deterrence seem dim. Alternatively, more recent cases, such as Wiwa, have selected targets that may be vulnerable to coercion, but whose contributions to the alleged injustice are, at best, secondary. Cases of this sort present a different problem, namely overdeterrence of legitimate risk-taking while failing to address, other than in a symbolic way, actual injustices. On balance, it seems problematic whether this litigation, evaluated solely in rationalist terms regarding its likely distributive effect, enhances welfare.

\section{The Pitfalls of Expressive Internationalism}

The ambitious approach to attacking international injustice through civil litigation embodies expressive internationalism. Lawyers and judges collaborate in a discourse that edifies global communities. It both teaches a lesson-that justice will out, once one comes to America-and offers other courts examples of how to do justice. This approach resonates with one influential strand of international relations theory, which emphasizes the constitutive and epistemic functions of legal process.

What's not to like? Actually, quite a lot. Some objections to internationally ambitious civil litigation go to difficulties with the expressive function, problems that the international context exacerbates. Put simply, the assertion of litigation's expressive value can, in practice, give rise to lawsuits that undermine rather than advance the good lessons to be taught. These perverse consequences reflect predictable responses to well-known aspects of the U.S. legal system.

58. Thus one of the oldest examples of human rights protection through international law, the commitment in the Treaty of Westphalia to respect religious minorities, is somewhat inapposite. On the connection between Westphalia and human rights, see Stephen D. Krasner, Sovereignty: Organized HyPOCRISY 79-82 (1999).

59. On the distinction between coordination problems and collective action problems, see Goldsmith \& Posner, supra note 55, at 1124-28: Paul B. Stephan, Courts, Tribunals and Legal Unification The Agency Problem, 3 CHI. J. INT"L L. 333, 338-40 \& n.7 (2002). 
Other objections point to the special problems of international expression. U.S. courts have no power to direct the conduct of foreign governments or their courts, and their interventions may lead to opposition rather than cooperation. These arguments suggest that the U.S. courts should work through the implications of the international institutional suspicion of our civil litigation system and reconsider some of their ambitious moves to broaden the reach of their conception of our justice. The distributive function, with all its limitations, may have more to recommend itself (or, more to the point, less to criticize) than its alternative.

\section{A. Exploitation}

Justifications for the expressive function of litigation in the pursuit of international justice assume that such lawsuits will either have no distributive impact or will have a benign effect due to compensation paid to victims and deterrence of future wrongdoing. What these arguments do not consider is that opportunistic litigants will use the tools designed to root out injustice to extort rents from vulnerable targets. But not considering the risk of such extortion, proponents ignore a significant cost of their proposal.

The risk of opportunism is a general problem of expressive litigation, not something specific to international expression. It arises because the expressive function by its nature requires judges not to privilege the distributive consequences of their statements and actions, even though the self-selection process for litigants reflects those consequences. Once courts create the possibility of a bounty, we should anticipate that litigants will claim it, even if the claimants do not fit comfortably within the class of persons that the expressive function wishes to benefit. There are many reasons to think that the rules of litigation permit poor fits between law and claimants, especially if judges label the law as aspirational and evolving.

Proponents of expressive litigation might argue that these costs are acceptable, given the benefits that come from expression. No human institution works perfectly, and we should not give up the quest for justice simply because fallible courts carry it out. Skeptics might respond that a serious evaluation of the costs and benefits remains necessary.

The tension between the relentless optimism of the proponents and the pessimism of a skeptic is illuminated by the contrasting visions underlying Wiwa and the Loewen claim. Wiwa confronted what on its face seems to be a far-fetched assertion that a prominent corporation, operating out of the heartland of European progressivism, "instigated, 
orchestrated, planned, and facilitated" the torture and murder of Ogoni activists opposed to the oil concessions that Shell had obtained from the Nigerian government. ${ }^{60}$ The court, of course, had to accept pleadings as if they were true when considering the kinds of procedural motions that were before it. Yet, the court surely knew that our civil litigation system does not have fail-safe systems in place to squeeze out meritless claims, and that large corporate defendants accordingly might attach positive settlement value to the lawsuit however groundless the allegation may be. In other contexts, the Supreme Court has adjusted jurisdictional and standing rules to kick out suits likely to present greater costs than benefits exactly at the point where discovery has not yet added to the claim's settlement value. ${ }^{61}$ The Wiwa court, confronted with the opportunity to follow traditional interpretations of personal jurisdiction and forum non conveniens doctrine, instead chose the path that forces the courts to take seriously ambitious, even preposterous claims.

The Loewen argument, if ultimately accepted by the arbiters, concentrates frankly on the distributive consequences of expressive acts. The Mississippi court had allowed the plaintiff's attorney to urge the jury to send a message to a wealthy foreign corporation and others like it. The verdict was intended to tell foreign investors that they could not take advantage of Mississippians. The crux of the Loewen argument is that messages of this sort come at too great a cost. If the United States wants to tolerate such expressive acts on the part of its state courts, the argument goes, it should underwrite the performance.

\section{B. Selectivity}

A point implicit in the description and justification of expressive litigation is that the content of the expression matters as much, if not more, than the nature of the expressor. It may be helpful that the litigation process presents an image of objectivity and prestige, but we still need a filter to sort those expressions that contribute to the progressive development of international justice from those that do not. A careful scrutiny of the cases and the literature suggests that political preferences, typically unstated, and not abstract normative principles, do this sorting work.

60. Wiwa. 226 F.3d at 92.

61. E.g. Asahi Metal Indus. Co. v. Superior Court of Cal., 480 U.S. 102 (1987) (dismissing products liability suit because of inadequate personal jurisdiction); Blue Chip Stamps v. Manor Drug Stores. 421 U.S. 723. $740-44$ (1975) (finding restrictive standing rules under securities laws justified by defects in litigation system). 
Cases where outsider groups-political dissidents or rural poorsuffer, seem to attract greater interest from the courts than do more conventional business disputes. Representative of the latter is $P T$ United Can Co. v. Crown Cork \& Seal Co. ${ }^{62}$ a case in which an Indonesian company sued its U.S. minority investor for various acts allegedly constituting fraud. The Second Circuit affirmed a dismissal based on lack of personal jurisdiction for some defendants and on forum non conveniens for the remainder. Taken at face value, the complaint alleged serious financial wrongdoing and grave economic loss. The court seemed to regard the possibility that a U.S. court could contribute to the development of the law governing fraud as insufficient to justify honoring the plaintiff's preference for a U.S. forum. Contrast this with Wiwa's insistence that U.S. courts had a special obligation to hold on to cases offering the prospect of contributing to the law of international human rights.

I do not mean to argue that courts should not let substantive preferences affect their resolution of procedural issues. That assertion would be both naive and insupportable. The issue is not whether judges bring their normative preferences into the litigation process, but how they do so and what constraints they acknowledge. I also do not believe that a distinction between political oppression and transaction wrongdoing is indefensible. But such a distinction is not ineluctable.

Considerable evidence supports the hypothesis that a judiciary willing to promote probity and reliability in business relationships will add significantly to the overall well-being of a society ${ }^{63}$ This evidence applies to the developing world, not just to the post-industrial economies. It suggests that the benefits of higher economic growth rates extend particularly to the more vulnerable residents of a developing country. One can extrapolate from these observations an argument that, to the extent U.S. courts heed an impulse to guide the rest of the world on the search for justice, they might do best by demonstrating how to combat fraud and corruption.

My larger point is that the decision to pursue an outsider rightsbased strategy for political and social justice may reflect a rich, older tradition of U.S. expressive litigation tied to the civil rights movement,

62. 138 F.3d 65 (2d Cir. 1998). See also Sussman v. Bank of Israel. 990 F.2d 71 (2d Cir. 1993).

63. See Paul G. Mahoney. The Common Law and Economic Growth: Hayek Might be Right. 30 J. LEGAL STUD. 503 (2001). Later work confirming Mahoney's claims include Edward L. Glaeser \& Andrel Shleifer, Legal Origins (Nat'l Bureau of Econ. Research. Working Paper No. 8272. 2001): Rafael. La Porta et al. The Guarantees of Freedom (Nat'l Bureau of Econ. Research. Working Paper No. 8759. 2002). 
rather than a deliberate judgment as to the needs of global justice. The courts seem to have assumed a familiar role without asking whether it fits the new challenges they face. In this sense, the ambitious international claims constitute a remarkably conservative use of the expressive function. The litigants and the courts have applied uncritically the lessons of the civil rights era to new, arguably radically different problems.

\section{Loss of Expertise}

We think of courts as providers of specialized services. The distributive function is uniquely judicial. Other branches of government do distribute (and redistribute) rights, privileges, duties, and powers, but only the judiciary does so on the basis of a retrospective inquiry that ties its distributive actions to a determination of preexisting facts and law. The expressive function requires the judiciary to go beyond this distinctive activity to articulate prospective normative judgments in a manner that is not readily distinguishable from that of the political branches of government or, in cases where the coercive power of the court is irrelevant, from academia.

The expressive function does not merely extend the distributive function, but in an important sense competes with litigation's retrospective assessment of concrete events. It is parasitical, inasmuch as the reputation for disinterested dispute resolution that distributive litigation produces gets spent in expression, while whatever good works expression achieves does not bolster the court's reputation for fairness and impartiality. Moreover, the two functions require different methodologies and perspectives. The expressive function addresses the future as much as the past. It presumes a change in the status quo caused by litigation's expression, as opposed to a confirmation or restoration of a status quo resulting from litigation's intervention. It exposes the court to a different kind of criticism by shifting debate from the validity of its reconstruction of the past to the reliability of its projections of the future.

That the expressive function comes at the cost of the distributive function would not matter if we attached little value to what the latter entails. But there are good reasons to believe that the uniquely judicial distributive function, which confirms reliable expectations in a disinterested and nonviolent fashion, contributes greatly to society's well-being. As we have learned from societies where the courts have found themselves unable to fulfill this function, law and all the good it can do cannot exist without credible institutions to apply its mandates. 
One also might argue that for the United States, the reputational capital of the litigation system is so great that some drawing down for the purposes of good expression would produce a net benefit for society. This view presumes a robustness of society's confidence in the courts without an adequate empirical foundation. True, people in the United States resort to the courts to pursue their grievances more frequently than do most other people, but this phenomenon may reflect a kind of arms race, in which people find themselves drawn to ambitious litigation claims in reaction to those made by others. Anecdotally, evidence that people see the judicial system as fundamentally and unfairly skewed in favor of repeat players, shameless claimants, and well-organized interest groups seems abundant.

\section{Noncooperation and Retaliation}

The arguments made in the previous three subsections apply to the expressive function generally, not just to litigation in pursuit of international interests. In this last subsection, I address the particular difficulty in using U.S. courts to foster international justice. The problem lies in the unwillingness of foreign states, including their judiciary, to go along with our project and their ability to sabotage it.

The resistance of foreign states to the ambitions of U.S. civil litigation is nothing new. Immediately after World War II, U.S. courts (led, one should note, by the Second Circuit) endorsed the application of U.S. antitrust law to conspiracies organized and run outside the United States that had the effect of harming U.S. consumers. ${ }^{64}$ Many first-world nations responded not with gratitude for instruction on how to promote competition, but with blocking statutes intended to frustrate the flow of information to U.S. plaintiffs and clawback laws designed to cancel the effects of antitrust trebled damages. ${ }^{65}$ At the judicial level, foreign courts (especially those of the United Kingdom) issued injunctions either to deny discovery to U.S. litigants or to forbid persons subject to their jurisdiction from prosecuting claims in the United States. ${ }^{66}$

Why did the other nations resist U.S. instruction on how to organize their economies? To some extent the conflict took the form of a zero-

64. See James A. Rahl, International Cartels and Their Regulation, in COMPETrTION IN INTERNATIONAl Business 240 (Oscar Schachter \& Robert Hellawell eds.. 1981 ).

65. See Gary B. Born, International Litigation in Untred States Courts 584-87. 84952 (3d ed. 1996).

66. See Rio Tinto Zinc Corp. v. Westinghouse Elec. Corp.. 1 A.C. 547 (H.L. 1978) (refusing to enforce letters rogatory emanating out of U.S. antitrust suit): Midland Bank PLC v. Laker Airways Ltd.. 1 Q.B. 689 (C.A. 1986) (issuing antisuit injunction against potential British plaintiff in U.S. antitrust lawsuit). 
sum struggle among national producers, and other countries suspected that the U.S. move would result in a net transfer of wealth from their producers to U.S. consumers with no offsetting benefits to their own consumers. Perhaps in other cases the home governments of the targeted defendants discounted the interests of local consumers for political economy reasons: concentrated producers, especially national champions, often have a significant political edge over dispersed consumers. At least some of the resistance, however, rested on a legitimate concern that private class-action lawsuits, fueled by supercompensatory damages and bolstered by discovery rules that impose a disproportionate burden on corporate defendants, may not be the best means of setting industrial policy.

The more recent expansion of the oversight of U.S. judges over foreign transactions also has provoked resistance. Consider as a concrete example the choice-of-law rule announced by the Second Circuit in Itar-Tass. That decision appears to make ownership of a U.S. copyright for expression originating in Russia turn exclusively on Russian law. Because of the political, economic, and social turbulence that has engulfed that country over the last fifteen years, determining Russian law as of a particular date can be, to put it mildly, problematic. Asking the Russian courts to decide an issue that may determine extremely valuable interests invites improper interference in the judicial function.

This exact dilemma lurks in the background of a suit now working its way through the U.S. courts. In the early 1990s, Films By Jove, Inc., a U.S. company, entered into a license agreement with a private Russian film studio covering the foreign copyrights for the large library of cartoons that the studio had made into its previous incarnation as a state enterprise. The Russian Civil Code, as of the time of the agreement, seemed to treat the studio as the owner of these rights and for most of the decade the Russian government so regarded it. When a legislator submitted a bill seeking to nationalize these rights, the government objected on the grounds that it would have to pay compensation for such an expropriation. But the government then brought a suit in its own courts asserting that the private studio did not own any property.

At about the same time, Films By Jove brought suit against a U.S. infringer of its copyright. The infringer promptly entered into a licensing agreement with the Russian government and asserted the superiority of its rights. The U.S. court, following Itar-Tass, then had to determine the state of Russian law at the beginning of the decade to ascertain whether the private Russian studio had the authority to 
enter into its agreement with Films By Jove. The parallel Russian litigation played a role in this inquiry, even though it appeared that the Russian government had taken the actions it did largely to influence the outcome of the U.S. case. Ultimately, the Russian courts produced confused and contradictory decisions that the U.S. trial judge (in my view correctly) concluded did not address the ownership of the copyrights. But these events suggest the kinds of perverse incentives that a choice-of-law rule can produce. ${ }^{67}$

The problem with Itar-Tass, as the Films By Jove example illustrates, lies in its giving to a foreign judiciary the power to determine $e x$ post the ownership of valuable U.S. rights. More precisely, it gives to the foreign court the power to decide ultimate facts governing claims to U.S. revenue, and not simply antecedent facts (e.g., such as whether the private studio existed as a valid Russian entity at the time it entered into the license agreement) that a U.S. court might consider in making its ultimate determination. The distinction matters, because power over ultimate facts is more vulnerable to abuse and less constrained by the need to appear consistent and lawlike.

The Itar-Tass problem represents only one instance of the many difficulties that may arise when a U.S. court addresses a foreign legal actor without considering the environment in which it functions. A country grappling with a recently violent past, for example, might reach a political settlement that includes an amnesty as consideration for disclosure or other commitment to future civility. A government seeking to attract foreign capital might make regulatory concessions to an investor. More generally, a nation may believe that any outside interference will undermine its efforts to grapple with its dark heritage by providing contending actors with easy scapegoats, reducing subtle issues to simple and unworkable categories, and distracting fruitful dialogue with futile inquiries. Any of these reasons might lead to resistance and retaliation.

The possibility of resistance matters, because the events that have given rise to the lawsuits in question remain largely under the control of foreign governments and beyond the reach of U.S. courts. One reason why the "second wave" lawsuits have focused on multinational corporations with a substantial presence in the United States is that these enterprises are susceptible to the U.S. legal process. They have U.S. assets and business prospects that they can enjoy only if they remain in the good graces of the judiciary, which in practice means

67. See Films By Jove. Inc. v. Berov. 154 F. Supp. 2d 432 (E.D.N.Y. 2001). My knowledge of these events stems from my role as an expert on questions of Russian law for Films By Jove. as the court opinion indicates. 
honoring any judgments entered against them. Once foreign governments refuse to cooperate, only defendants of this sort bear the consequences of U.S. litigation.

Holding only firms that do business in the United States accountable for misdeeds in which foreign governments collaborate is not only unjust, but can be perverse. If those governments feel justified in the choices they make, or at least reject the interference of U.S. judges, they usually can engage firms that operate beyond the power of those judges. The ongoing litigation over the alleged use of slave labor in the building of a Burmese pipeline nicely illustrates the point: Unocal, a California company, faces the prospect of liability for its participation in this project, but Total, a French firm with no substantial presence in the United States, does not. ${ }^{68}$

The more general point is that U.S. lawsuits motivated by expressive concerns run the risk of goading foreign governments away from moderation and reconciliation and toward intransigence. Such an outcome would be exactly the opposite of what the expressive function should aspire to achieve. Yet it seems quite realistic given current U.S. practice.

\section{Unilateralism, International Cooperation, and THE Judicial FunCtion}

The above comparison of litigation's expressive and distributive functions raises more general questions about international relations. At the risk of oversimplification, I wish to suggest a connection between the position one might take on judicial unilateralism in the service of expressive goals and that on the rightness of unilateral action by the U.S. government on matters of international concern. On the one hand, proponents of the expressive function also tend to bemoan the unwillingness of the United States to subordinate its national interests to cooperative projects such as the Kyoto Protocol, the International Criminal Court, or multilateral prosecution of the war against terrorism. ${ }^{69}$ On the other hand, critics of the expressive trends in U.S. civil litigation tend to have fewer problems with the government's uni-

68. Doe I v. Unocal Corp.. ___F.3d __ (9th Cir. 2002) (holding U.S. firm subject to suit): Doe v. Unocal Corp.. 248 F.3d 915 (9th Cir. 2001) (holding French firm not subject to suit).

69. E.g., Harold H. Koh. The Case Against Military Commissions. 96 Am. J. INT'L L. 337 (2002); Harold H. Koh. The Spirit of the Laws, 43 Harv. INT"L L.J. 23 (2002); Harold H. Koh, A United States Human Rights Policy for the 2Ist Century, 46 ST. Lous U. L.J. 293 (2002): AnneMarie Slaughter, Building Global Democracy, 1 CHI. J. INr'l. L. 223 (2000); Anne-Marie Slaughter, Beware the Trumpets of War: A Response to Kenneth Anderson, 25 Hakv. J.L. \& PuB. PoL'Y 965 (2002): Anne-Marie Slaughter \& William Burke-White. An International Constitutional Moment. 43 HARV. INT'L L.J. 1 (2002). 
lateralism. ${ }^{70}$ Is there a contradiction in these positions? What justifies unilateralism in one arena, whether litigation or government decisionmaking, and not the other?

These questions admit several responses. First, neither the critics nor supporters of unilateralism in either context-judicial or governmental-embrace or deplore unilateralism as an abstraction. The proponents of the expressive function in litigation do not support expression vel non, but rather the particular values of decency and compassion that underlie lawsuits brought against violent or debauched governments and firms. The critics of U.S. governmental unilateralism do not object per se to U.S. leadership, but rather, in the instances currently in dispute, prefer the policies promoted by the collective bodies to those of the present U.S. administration. ${ }^{71}$ What we may see, in other words, is not a contest over the desirability of either judicial or governmental unilateralism, but rather a debate about particular policy preferences disguised in more abstract categories.

This deconstruction of the matter, however, seems too facile. The scholars on both sides may have political commitments, but they also use great analytical power and lucid rhetorical skill to address questions that transcend the controversies of the moment. Their arguments deserve careful consideration on their own terms.

For those that see the expressive function as central to both civil litigation and international relations, arguments about unilateralism versus cooperation should be irrelevant. The expressive voice, and what is expressed, matters. The choice between the lonely voice beckoning the rest of the world and the harmonious chorus of international cooperation should turn on the ends desired, with the appropriate means a matter of happenstance.

All the same, there is something odd about the way the expressive function currently is invoked by some of the leading commentators. On the one hand, it justifies the expansion of judicial autonomy in areas where the other branches of government, and particularly the Executive, traditionally have played the major role. On the other hand, it deplores the efforts of the Executive - at least since 2001-to take the initiative on matters of international consequence. The ex-

70. E.g. Curtis A. Bradley \& Jack L. Goldsmith. The Constitutional Validity of Military Commissions. 5 Green Bag 249 (2002): Jack L. Goldsmith. The Self-Defeating International Criminal Court. 70 U. CHI. L. Rev. (forthcoming 2002).

71. In particular, many of the critics of U.S. leadership in the last two years had far fewer reservations about the initiatives of the Clinton Administration. See, e.g.. John C. Yoo. The Dogs That Didn't Bark: Why Were International Legal Scholars MIA in Kosovo?. 1 CHI J. INT"L L. 149 (2000): John C. Yoo, Kosovo. War Powers, and the Multilateral Future. 148 U. PA. L. REv. $1673(2000)$. 
pressive, it seems, has become not so much instructional as oppositional. It cheers on that branch of the government where those outside politics can challenge what politicians do, while urging the political branches to subordinate their impulses and desires to the counseling and deliberation of other nations. Expression seems to function more as opposition to politics than as its complement.

For those that find in the distributive function a more satisfying normative account of judicial behavior, the tension between the limited aspirations of litigation and lesser constraints on the political branches requires some attention. If unilateral efforts by the judiciary to instruct and elevate foreign actors invite resentment and retaliation, won't comparable actions by the U.S. government produce similar reactions? From the perspective of the rest of the world, does it matter which arm of the United States meddles, nags, and shows no regard for the opinions of others?

These questions have plausible answers, but they rest on assumptions about domestic legal and political institutions and not about international relations. In particular, the argument rests on the complements of the first three arguments I made in the previous section, namely the claims that expressive litigation may lead to exploitation, selectivity, and loss of judicial expertise. The common thread is that none of these arguments applies to the political branches.

First, the risk of exploitation in litigation arises because of weak constraints on the kinds of suits that get filed and the potential for perverse incentives to litigants. Because of the difficulty (and in the case of constitutional determinations, the impossibility) of enacting legislation to overturn litigated outcomes, the judicial system faces only indirect and diffuse accountability for the consequences of its decisions. In contrast, political decisionmaking presents a different set of vulnerabilities and biases. One can hardly argue that interested actors cannot exploit the political branches, but the means of undoing such exploitation generally are more readily at hand. As a result, this one reason for judges to focus more on the significance of the parties and facts before them, and less on the possible ramifications of their words and action, does not apply to the political branches.

Second, the selectivity problem undercuts the expressive power of litigation by blurring the message. The political branches, by contrast, have a looser connection to the expressive function and operate more as mediators among contending claimants for scarce resources. The inevitability of selectivity thus interferes less with the function of the political branches and does less to undermine their legitimacy. 
Third, loss of expertise is a problem specifically of the judiciary's political capital, and has no bearing on the functioning of the political branches. For better or worse, the political branches do not depend for their legitimacy on a general impression of impartiality and lawfulness. As a result, particular actions in the international arena may impair the actor (if things turn out badly) without necessarily undermining the Executive or Congress as institutions. Mistakes may impair the President (one thinks of the Iran hostage crisis and the Carter Administration) without weakening the presidency.

None of these arguments proves the case for unilateralism in international relations. Rather, they make the more modest point that no principled reason exists for insisting on consistency in how the three branches of the U.S. government interact with the rest of the world. One can criticize the courts' tendency to hector the rest of the world to do better without surrendering the right to urge the other branches to do the same. Put differently, good institutional arguments exist for resisting judicial unilateralism across the board. Similar institutional arguments suggest that the political branches can and may act unilaterally when pragmatic reasons justify such action. Such pragmatism in the hands of the judiciary becomes more problematic.

\section{CONCLUSION}

For decades, the United States has tried to induce the rest of the world to provide stable legal regimes that will support investment and enterprise. It pursued this goal both by example (bolstered by certain constitutional commitments, particularly the Takings Clause) and through treaties. It entered into the latter thinking that making a promise against expropriation would cost nothing because of those commitments. Discovering that these treaties put under a cloud one function of the civil litigation system, a function that some have celebrated and many have tolerated, has come as quite a shock.

One might wiggle out of this difficulty by dismissing the state court decisions that have triggered international legal scrutiny as aberrant and in any event unrelated to the ambitious federal court cases that this Article has discussed. If anything, one might argue, the fact that some isolated state courts behave in a fashion that invites international opprobrium strengthens the case for a more activist federal court that displaces wider areas of state law with federal rules and principles. If Congress has not yet enacted such laws, or at least has not taken clear and specific steps to do so, the federal courts should fill the gap with their own interstitial lawmaking. 
This argument draws the wrong lesson from the dispute. What is interesting about the international law critique of U.S. civil litigation is not the focus on aberrant state courts but the rejection of the very premises of the expressive function. Courts, the critique suggests, should decide the controversies before them based on the evidence presented and reasonably accessible and transparent principles of law. When they do otherwise, and someone suffers as a result, a rending in the fabric of international stability, justice, and morality has occurred. If a treaty applies, a remedy results.

I do not mean to suggest that this critique is so overwhelming that all should fall before it; that U.S. judges should abandon any sense of mission and seek only to resolve the disputes before them in as mechanical a fashion as possible. What I do believe is that the international law critique deserves a fair hearing, and that some judges conscientiously might regard it as a basis for reining in some of their more venturesome claims and broader ambitions. The tension between the expressive and distributive functions may be irreducible, but a new and better balance is attainable. 